\title{
O analista de discurso e a práxis sócio-histórica: um gesto de interpretação materialista e dialético
}

\author{
Helson Flávio da Silva Sobrinho ${ }^{1}$
}

\begin{abstract}
Resumen: Este artículo, inscrito en la perspectiva del Análisis del Discurso de Michel Pêcheux y con fundamento en el materialismo histórico y dialéctico, busca contribuir con la teoría y la práctica del analista del discurso. Pretende, sobre todo, reabrir cuestiones sobre el carácter ético, político y la responsabilidad de nuestro gesto teórico metodológico de descripción-interpretación que siempre, a partir de la relación sujeto-objeto, una relación determinada históricamente implica, de modo incontenible, el hacer ciencia y el hacer política al mismo tiempo, pues no se relaciona de modo tangencial la praxis socio histórica.
\end{abstract}

Palabras clave: discurso; marxismo; práxis; ciência; política.

Resumo: Este artigo, inscrito na perspectiva da Análise do Discurso de Michel Pêcheux e fundamentado no materialismo histórico e dialético, busca contribuir com a teoria e a prática do analista de discurso. Visa, sobretudo, reabrir questões sobre o caráter ético, político e de responsabilidade do nosso gesto teórico-metodológico de descrição-interpretação que, a partir da relação sujeito-objeto, sempre uma relação determinada historicamente, implica, de modo incontornável, o fazer ciência e o fazer política ao mesmo tempo, pois não se pode tangenciar a práxis sócio-histórica.

Palavras-chave: discurso; marxismo; práxis; ciência; política.

\section{Palavras iniciais: o (des)conforto de estar e trabalhar no entremeio das contradições}

“A arma da crítica não pode, é claro, substituir a crítica da arma. O poder material tem de ser derrubado pelo poder material, mas a teoria também se torna força material quando se apodera das massas. A teoria é capaz de se apoderar das massas tão logo demonstra $a d$ hominem, e demonstra ad hominem tão logo se torna radical. Ser radical é agarrar a coisa pela raiz. Mas a raiz, para o homem, é o próprio homem." (MARX, [1843], 2010, p. 151)

"Sem teoria revolucionária não pode haver também movimento revolucionário." (LENIN, [1902], 1977, p. 96)

"Não há dominação sem resistência: primeiro prático da luta de classes, que significa que é preciso 'ousar se revoltar'.” (PÊCHEUX, [1982], 1997b, p. 304)

Diante de falas concordantes e/ou discordantes e posturas críticas e acríticas sobre a chamada "banalização/vulgarização/despolitização"2 dos conceitos da Análise do Discurso

1 Doutor em Letras e Linguística. Professor e pesquisador da Universidade Federal de Alagoas (UFAL). Pesquisador do Grupo de Estudos em Discurso e Ontologia (Gedon).

2 Sobre a "banalização" dos conceitos da Análise do Discurso na França, conferir D. Maldidier (2003), e sobre a "despolitização" da AD, ver Courtine (1999, p. 11): "Havia uma análise do discurso que queria articular história e lingüística. Existem agora $n$ análises de discurso que, em sua maioria, abandonaram tal projeto". 
(AD) e do legado de Michel Pêcheux, compreendemos a necessidade de pensar sobre a nossa prática e refletir sobre quem somos e o que fazemos. E mais, indagar: por que (e para quem) fazemos o que fazemos? Começar por essas perguntas pode assemelhar-se a um tipo de esquisitice/evidência/absurdo semelhante ao gesto de la Palice e/ou Barão de Münchhausen, mas é uma forma de inquietação que faz valer a crítica à afirmação do óbvio, especialmente porque elas podem nos levar a refletir sobre o que efetivamente nos preocupa na conjuntura atual e, assim, dialeticamente, contribuir com a teoria e a prática do analista de discurso. Em suma, nosso gesto de interpretação ${ }^{3}$ busca reabrir questões sobre o caráter ético, político e de responsabilidade de nossa prática teórica e metodológica de descrição-interpretação. Esta, a partir da relação sujeito-objeto (sempre uma relação determinada historicamente), implica, de modo incontornável, o fazer ciência e o fazer política ao mesmo tempo.

Michel Pêcheux buscou sempre em suas autocríticas retificar, mas também ratificar questões no quadro teórico e metodológico da AD (Marxismo, Linguística e Psicanálise), a fim de trabalhar no entremeio das contradições - e isso sempre foi para ele um ponto complexo de natureza teórica e política. Ressaltamos que trabalharemos na complexa relação contraditória entre Sujeito, Língua e História, e, por isso, buscaremos não recobrir a luta de classes quando falarmos de discurso e de prática teórico-analítica. A consequência desse gesto é que precisaremos trafegar na contramão do saber dominante, tomando partido e, sobretudo, assumindo, a partir de uma perspectiva materialista-dialética, uma posição na luta resistência-revolta contra o sistema capitalista.

Posto isso, iniciemos, pois, com as citações em epígrafe dos três autores, tidos para o pensamento burguês da atualidade como "nomes malditos" e, por isso, "impronunciáveis"; ou ainda, como "cachorros mortos", pois hoje a luta de classes não é tida como uma questão central, sendo muitas vezes até considerada como inexistente ${ }^{4}$. Para contestar essa posição ideológica dominante, vamos aos trechos das obras desses teóricos de posição materialista e dialética. Na primeira citação, temos Karl Marx nos alertando que o poder material deve ser combatido na práxis sócio-histórica pelo poder material; ao mesmo tempo, entretanto, Marx destaca que a teoria é essencialmente relevante, pois se torna força material quando chega à raiz das questões e adentra a consciência do sujeito para intervir nas lutas. Em continuidade, na segunda citação, retirada do texto Que fazer? de Lenin, esse teórico-militante e revolucionário afirma: "Sem teoria revolucionária não pode haver também movimento revolucionário", o que nos possibilita compreender a importância da teoria e do gesto teórico-analítico nas práticas revolucionárias. Na última citação, de Michel Pêcheux, vemos uma forte convocação à luta, já que "não há dominação sem resistência: primeiro prático da luta de classes, que significa que é preciso "ousar se revoltar"”.

A partir desse quadro que demonstra ser a História a História da luta de classes, é preciso que nos revoltemos diante dos problemas colocados pela lógica do capital, pois, particularmente no Brasil, há inúmeras questões que nos afetam cotidianamente e nos exigem respostas radicais e efetivas. Reafirmamos, por isso, a necessidade do materialismo histórico e dialético, visto que nos confrontamos com acontecimentos que exigem uma análise discursiva de caráter revolucionário e não um retorno à filosofia burguesa, incapaz de uma

3 Estamos tomando de empréstimo a noção de Orlandi de gesto de interpretação como prática discursiva (sócio-histórica) que intervém no mundo. Segundo a autora (1996, p. 17 e 18), "o gesto de interpretação, fora da história, não é formulação (é fórmula), não é re-significação (é rearranjo). [...] A interpretação é o vestígio do possível. É o lugar próprio da ideologia e é 'materializada' pela história".

4 Cf. Silva Sobrinho (2011), "Análise do Discurso e a insuportável luta de classes na teoria e na prática”. 
crítica radical ao capitalismo. Em síntese, como vimos, as três citações pressupõem a luta de classes (dominação/resistência-revolta) como o motor do processo histórico; por isso, não podemos minimizar a importância da teoria e da práxis, que devem avançar dialeticamente no processo dinâmico e contraditório da relação do sujeito com o real sócio-histórico.

\section{0 analista de discurso e a práxis sócio-histórica}

Diante das questões já colocadas na presente reflexão, é importante enfatizar que a relação entre o analista de discurso (sujeito histórico) e a práxis sócio-histórica tem seu fundamento último nas condições de reprodução/transformação das relações de produção. Trata-se da existência das determinações sócio-históricas, ideológicas e também inconscientes que afetam e constituem o analista, pois estamos inscritos em lugares/posições materiais de classes (antagônicas) num determinado modo de produção histórico-concreto. Daí advém nosso aprofundamento na teoria da Análise do Discurso pelo viés da perspectiva marxista, para compreender e também fazer trabalhar uma concepção de História e de discurso que leve em consideração a práxis sócio-histórica dos sujeitos a partir das forças produtivas e das relações sociais de produção e suas materializações no funcionamento da linguagem. O que está em jogo nessa discussão é a categoria Condições de Produção, pois, como diz Zandwais, "o conceito de condições de produção tomado do materialismo histórico [...] viria a criar as condições para inscrever, de modo concreto, a história na ordem do discurso e o discurso no campo da práxis" (2009, p. 22). Podemos acrescentar que esse gesto deve ser tomado como algo decisivo na Análise do Discurso, pois impulsiona o questionamento eficaz da estrutura econômica do capitalismo, combatendo, sobretudo, suas relações de exploração.

$\mathrm{Na}$ teoria marxista a base da atividade vital humana é a relação que os sujeitos estabelecem com a natureza, pois o trabalho é a categoria fundante do ser social ${ }^{5}$. Essa atividade de caráter material responde às carências e às necessidades dos sujeitos em sua práxis cotidiana, e tais respostas dão origem a novas necessidades, num eterno vir a ser dos sujeitos e das relações sócio-históricas que eles estabelecem entre si. É desse modo que a socialização é desencadeada pelo trabalho, e este, em sua dialética, não só transforma a natureza, mas também transforma o próprio sujeito, que é radicalmente um ser social e histórico ${ }^{6}$. Para Marx e Engels (2004), a base real de toda história é a existência dos sujeitos vivos desenvolvendo ações e meios de sobrevivência em condições materiais de produção. Isso remete à produção da vida material em sua cotidianidade histórica.

Como a História é resultado da práxis humana e resulta da produção, reprodução e transformação social, por esse caminho é que nos direcionaremos ao conceito de práxis sócio-histórica. Segundo Vázquez (2007), a filosofia marxista é uma filosofia da práxis, uma atividade humana, real e efetiva, de caráter transformador que leva em consideração as condições materiais de existência. Ou seja, "Como filosofia da práxis, o marxismo é a consciência filosófica da atividade prática humana que transforma o mundo. [...] revela seu fundamento, condições e objetivos - como também tem consciência dessa relação e, por isso, é um guia da ação" (VÁZQUEZ, 2007, p. 171).

5 "Primeiro o trabalho e, depois dele e com ele, a palavra articulada, forma os dois estímulos principias sob cuja influência o cérebro do macaco foi se transformando gradualmente em cérebro humano - que, apesar de toda sua semelhança, supera-o consideravelmente em tamanho e em perfeição.” (ENGELS, 2004, p. 16).

6 Segundo Marx (2004, p. 119): "a essência humana não é uma abstração inerente ao indivíduo isolado. Em sua realidade, é o conjunto das relações sociais". 
Esse fundamento que toma a atividade humana, o trabalho, como a protoforma do ser social é importante porque revela a articulação essencial e dialética entre teoria e ação. Por isso, podemos analisar também a forma como o trabalho (estranhado) aparece nas sociedades de classes, pois o objeto de trabalho não pertence ao trabalhador, e as relações entre os sujeitos são relações de exploração. A divisão social do trabalho (cidade/campo e físico/intelectual) e a propriedade privada dos meios de produção, na sociedade capitalista, transformam tudo em mercadoria, até mesmo a força de trabalho, o que implica o processo de coisificação do sujeito, como esclarece Coutinho:

Todas as relações sociais entre os homens aparecem sob a forma de relações entre coisas, sob a aparência de realidades "naturais" estranhas e independentes da sua ação. Os produtos da atividade do homem social, desde a esfera da economia à cultura, revelam-se aos indivíduos como algo inteiramente alheio à sua essência; opera-se uma cisão entre a essência (a práxis criadora) e a existência (a vida social) dos homens. (COUTINHO, 1972, p. 24).

Assim, no capitalismo, os sujeitos assumem determinados lugares e posições nas relações desiguais que, como afirma Marx (2004), se resumem em duas posições de classes: "proprietários e trabalhadores (sem propriedade)". Portanto, esse processo social contraditório e estranhado afeta radicalmente os sujeitos históricos e a discursividade, pois as relações sociais, dialeticamente, determinam o processo discursivo e são determinadas por ele, ou seja, efeito e trabalho (PÊCHEUX, 2002). Consideramos que Michel Pêcheux não se afasta dessa posição marxista, já que sua concepção de História aparece de modo fecundo no livro Semântica e Discurso, quando justifica sua inscrição teórico-política: “[...] na perspectiva de uma análise materialista do efeito das relações de classes sobre o que se pode chamar as "práticas lingüísticas"” (1997a, p. 24). Essa inscrição é uma busca de não excluir a História, o sujeito e a sociedade, nem recobrir a política e a ideologia, como o fizeram o sociologismo e logicismo em Linguística, e o conteudismo em Psicologia e Ciências Sociais. Pêcheux, ao trabalhar com a prática científica e política, buscava desvendar a produção de sentidos a partir da teoria materialista dos processos discursivos, articulando o dizer com as condições ideológicas de reprodução/transformação das relações de produção. Ao questionar a base linguística (relativamente autônoma) e explicar o funcionamento ideológico dos processos discursivos, Pêcheux demonstra como ocorre a divisão discursiva - direta e/ou indiretamente afetada pela base econômica (material) - nas relações sociais, políticas, jurídicas e ideológicas, desvelando como essa divisão materializa, reproduz e transforma, dialeticamente, as próprias relações de trabalho.

Assim, o discurso não tem uma gênese espontânea (abstrata/pura), pois é gerado e sustentado pela e nas condições materiais de existência dos sujeitos históricos. Esse complexo faz com que a forma de ser de cada sociabilidade seja condição fundamental da discursividade, pois está entrelaçada com as atividades historicamente determinadas. Por isso, o processo concreto real de produção material é o fundamento da História, e nessa direção, a subjetividade, na sociedade capitalista, é constituída nas/pelas contradições do antagonismo entre capital e trabalho, que constitui, por sua vez, contraditoriamente, as práticas discursivas. $\mathrm{O}$ processo é verdadeiramente complexo, uma vez que o discurso é gerido na atividade prática do ser social, na base material, onde há sujeitos reais reproduzindo/transformando seus meios de vida e sua própria vida, pois não há dialética histórica sem sujeitos transformadores. Como diz Lukács (1981, p. 60), "a dialética materialista é uma dialética revolucionária”, porque sua essência é a unidade entre teoria e prática, tomada de consciência e operação decisiva no real, ou seja, possibilidade de compreender e intervir na dinâmica sócio-histórica. 
Desse ponto de vista, consideramos também que a práxis do analista de discurso está intrinsecamente articulada ao processo sócio-histórico e sofre as vicissitudes e nuanças da divisão social do trabalho, das hierarquias sociais, da luta de classes. Segundo Pêcheux (1997a, p.189), "não há discurso científico puro", o que nos faz compreender também que - apesar de possuirmos um aparato teórico e instrumental amadurecido, de reconhecermos que trabalhamos com a descrição-interpretação e no entremeio das contradições - o gesto analítico e sua implicação sócio-histórica não nos são transparentes. É que somos constituídos pela ideologia e afetados pelo inconsciente e, sobretudo, vivemos em meio às práticas determinadas historicamente e desempenhamos alguma função - sempre de caráter paradoxal - de submissão e/ou de resistência-revolta no processo produtivo, marcado pela divisão social do trabalho.

Assim, mesmo intentando uma relação menos ingênua com a linguagem e sabendo da existência de causas que nos determinam, algo escapa na nossa prática analítica, podendo, inadvertidamente, derivar para uma prática científica aparentemente "desinteressada/ despolitizada" e/ou "voluntarista/subjetivista". E, já que corremos riscos, é importante ressaltar que nossa prática está, de modo incontornável, imbricada nas relações sociais de reprodução/transformação das condições de produção, pois o fazer ciência e o fazer política não escapam da lógica do capital, que cada vez mais potencializa sua exploração de infinitas formas, por exemplo: na qualificação e desenvolvimento de "competências"; na exigência de técnicas quantificadoras de nossa "produtividade"; na aplicação prática imediatista da teoria para "solucionar" problemas político-econômicos em seu caráter fenomênico, evitando assim tocar efetivamente na raiz das questões; na dissimulação dos interesses dominantes pelo "consenso" em defesa da "democracia" burguesa tomada sempre como valor universal e eterno; nas contradições sociais através da exigência da ininterrupta competitividade fomentada entre os sujeitos pela produção de "inovações" e consequente submissão à lógica do mercado.

Desse modo, a perspectiva teórico-política burguesa impede a compreensão da totalidade social concreta, pois não visa à crítica ao capitalismo, neutralizando por vezes a práxis revolucionária. A nosso ver, fazer AD é sempre uma prática desafiadora na conjuntura histórica de reprodução/transformação das relações de produção, ou seja, o fazer ciência e política é, ao mesmo tempo, parte constitutiva das relações antagônicas existentes entre capital e trabalho. Portanto, nossa prática (confortável e/ou desconfortavelmente) tem conexões com determinadas classes, porquanto não pode estar isolada da práxis sócio-histórica.

\section{O fazer ciência: uma questão de ética, política e responsabilidade}

Pêcheux (2002, p. 57), em Discurso: estrutura ou acontecimento?, finaliza seu texto enfatizando: "em face das interpretações sem margens nas quais o intérprete se coloca como um ponto absoluto, sem outro nem real, trata-se aí, para mim, de uma questão de ética e política: uma questão de responsabilidade". Ao retomar esse dizer, estamos interpretando-o pelo viés marxista para compreender a prática teórico-analítica e política na sua devida gênese, ou seja, nas contradições do real com suas determinações históricas e posições ideológicas de classes.

A esse respeito, é preciso reafirmar que o discurso é também produto (materialidade) da sociedade burguesa, e quando o analisamos, estamos também desempenhando alguma "função" no processo produtivo, já que não estamos fora das classes sociais. Assim, nossa leitura e nossa escrita analítica são sempre um gesto político que desafia o contexto histórico, 


\section{Conexão Letras}

pois nos deparamos com a opressão, a violência, a repressão, a desilusão e o conformismo, mas também com a indignação, o inconformismo, a esperança, a resistência-revolta e a luta pela emancipação humana. A cada análise temos o compromisso de elucidar o processo discursivo em seu movimento dialético no processo histórico que está, em última instância, inscrito nos antagonismos inconciliáveis das classes sociais do modo de produção capitalista. E é assim que buscamos compreender/intervir nas práticas históricas de nosso tempo. Desse modo, podemos dizer que fazer AD é para nós uma perspectiva de trabalho de resistência-revolta e luta contra a opressão do capital.

Diante dessas formulações, e para não nos desviarmos da posição assumida de resistência-revolta, é preciso julgar sobre fatos e não deixar que nosso discurso se autonomize em uma reflexão cheia de abstrações, ao modo de um teórico de gabinete. Por isso, traremos aqui duas análises de questões, todas elas perpassadas pela luta de classes, para contribuir com a crítica à sociedade burguesa. Na primeira, o foco é sobre uma materialidade discursiva de caráter acadêmico-científico; na segunda, o olhar se dá sobre questões de caráter acadêmico-sindical. A proposta é trabalhar na contradição entre fazer ciência e política na formação social capitalista. Esse gesto é algo mais que simbólico, pois expõe os mecanismos de poder da ideologia que "sutilmente", enquanto profissionais da área, também nos coloca diante da ofensiva do capital.

Comecemos pela análise de algumas sequências discursivas (SD) retiradas do projeto "Prêmio Jovem Cientista", de 2011, cujo tema foi "Cidades sustentáveis":

1.O futuro do país está nas salas de aulas, nas bibliotecas e nos laboratórios das escolas e universidades. Em uma palavra, o futuro está na Educação. (...) Ao premiar o esforço de cada estudante e pesquisador em encontrar e propor soluções que melhorem o dia a dia dos cidadãos, o Prêmio Jovem Cientista ajuda a pavimentar o caminho para um Brasil mais sustentável e desenvolvido.

2. À concessão de prêmios, uma ação tradicional do CNPq, buscou-se imprimir maior visibilidade, junto à sociedade, da importância das atividades de CT\&I para o desenvolvimento do país. A utilização desse importante instrumento de política científica e tecnológica, paralelamente a uma mobilização crescente dos diversos atores associados à produção técnico-científica, insere-se nos esforços de uma articulação mais efetiva com instituições do setor privado. Esta ação tem funcionado, assim, como um incentivo para impulsionar a formação de estudantes, jovens pesquisadores e profissionais empenhados na busca de soluções para desafios da sociedade brasileira.

3. O Prêmio Jovem Cientista é uma parceria entre o Conselho Nacional de Desenvolvimento Científico e Tecnológico, a Gerdau, a Fundação Roberto Marinho e a GE, e tem como objetivos promover a reflexão, estimular a pesquisa e revelar talentos, além de investir em estudantes e profissionais que procuram alternativas para os problemas brasileiros.

O "Prêmio", em sua espessura histórica discursiva, com sua transparência/opacidade, responde à demanda das relações sociais de produção, buscando "soluções" criativas para os "problemas" contundentes de nossa existência histórica. Mas, como diz Pêcheux, "todo processo discursivo se inscreve numa relação ideológica de classes" (1997a, p. 92); assim, vemos que a criatividade se dá a partir do funcionamento da ideologia dominante que interpela o "Jovem Cientista", convocando-o para "livremente" "assumir" o "seu lugar", pois o "Jovem Cientista" (e não o velho cientista) é tido como sujeito, em potencial, para encontrar "soluções/alternativas" aos "desafios/problemas da sociedade brasileira". O pressuposto é que para o discurso da Ciência (com C maiúsculo) é possível "solucionar" 
diversas problemáticas através da produção do conhecimento, o que culminará em propostas de intervenções na sociedade. Essa intervenção faz valer os interesses hegemônicos e propõe "soluções" tidas como "alternativas" para manter a ordem do social sem que se efetive uma prática revolucionária.

Esse recrutamento do "Jovem Cientista" é uma tomada de posição (ideológica) de classe. Para constatar isso foquemos nossa análise no objetivo do concurso: "Ao premiar o esforço de cada estudante e pesquisador em encontrar e propor soluções que melhorem o dia a dia dos cidadãos, o Prêmio Jovem Cientista ajuda a pavimentar o caminho para um Brasil mais sustentável e desenvolvido". Assim, como todo espaço discursivo, esse dizer é determinado pelo que pode e deve ser dito em uma formação discursiva que materializa posições ideológicas no discurso. "Premiar" o "esforço" do "Jovem-estudante-pesquisador" que busca "soluções" para "melhorar" o "dia a dia" dos "cidadãos" no "caminho" para um "Brasil" "mais sustentável" e "desenvolvido" tem o atravessamento de pré-construídos que revelam, pelo domínio de saberes, a força material do discurso e os interesses ideológicos em jogo.

Esse é o caráter alienante, utópico e universalizante de uma "Ciência" que se coloca a serviço do poder e que, ao propor "soluções" para os problemas sociais, "pensa" ser a fonte de sentido, quando, em verdade, discursiviza de um ponto de vista em defesa da economia burguesa. Estamos aqui diante do que Lukács, fundamentado em Marx, chama de defesa burguesa do progresso [neste caso, chamado de "desenvolvimento"] e da crítica romântica ao capitalismo (1981, p. 114). Assim, pois, se há problema na ordem da "sustentabilidade" e do "desenvolvimento" brasileiro, essa questão deriva em parte da nossa história de colônia de exploração, fruto do próprio "desenvolvimento" do capitalismo tardio, período de acumulação primitiva do capital. Mas resulta, também, das políticas econômicas do Império e da República, passando pelo Golpe militar e chegando às políticas neoliberais levadas a cabo pelos governos brasileiros. Por fim, o problema se entrelaça ao atual período de crise econômica que assola "globalmente" as sociedades capitalistas "centrais" e "periféricas".

O que vemos é que a necessidade de resoluções de "problemas" via Ciência (Jovem Cientista) manifesta os interesses privados que vêm se associar à pesquisa para continuar reproduzindo as relações de produção (exploração) da sociedade regida pela lógica do capital. Diante dessas sequências discursivas, pensamos como os interesses dominantes atravessam e constituem essas materialidades. Não precisamos nos alongar na busca por respostas; basta atentar para os "parceiros" do "prêmio": "Fundação Roberto Marinho, Gerdal e GE”. Essa materialização do discurso "parceria" demonstra como se coadunam os interesses político-econômicos da burguesia e a prática científica, pois "insere-se nos esforços de uma articulação mais efetiva com instituições do setor privado". É característico nessa sequência discursiva aquilo que disseram Marx e Engels: "As idéias dominantes, são, pois, nada mais que a expressão ideal das relações materiais dominantes [...] são, dessa forma, as idéias de sua dominação" (MARX \& ENGELS, 2004, p. 78).

De fato, na sequência discursiva acima, vemos que, sem defender explicitamente o sistema capitalista, a política científica que interpela, "incentiva" e "premia" o "Jovem Cientista" para encontrar "inovadoras" "soluções" às mazelas produzidas pela lógica do capital direciona - através do discurso da "sustentabilidade" - o saber/fazer para a continuidade do "desenvolvimento" do capitalismo, e não para sua superação-revolução. Como diz Pêcheux (1997a, p. 91), "os processos ideológicos simulam os processos científicos". Assim, vemos também como os proprietários do capital medeiam o fazer ciência e orientam a forma possível de intervenção nas relações de produção. Dessa maneira, na prática, 
ciência e política incorporam-dissimulam os elementos do interdiscurso no intradiscurso e fazem com que, como diz Pêcheux (1997a, p. 160), as palavras mudem de sentido segundo as posições sustentadas por aqueles que as empregam.

Vejamos agora, após termos passado pela produção de evidência de sujeito/sentido da ciência e suas "premiações", um segundo caso também exemplar da relação discurso e práxis sócio-histórica na sociedade regida pelo capital. Trata-se de uma questão acadêmico-sindical, mais especificamente, a política sindical do fazer universidade. Para isso, tomaremos recortes de enunciados do sindicato dos professores do ensino superior.

A fim de resgatar as especificidades dessa questão, precisaremos lembrar que entre julho e setembro de 2011 vivenciamos, nas Universidades Federais brasileiras, um debate/embate entre professores, funcionários, estudantes, sindicatos e o Estado, em torno de questões salariais, plano de carreira, qualidade de ensino, infraestrutura, expansão universitária, jornada de trabalho e precarização do trabalho, segurança, direitos sociais, e outros pontos importantes da conjuntura histórica. Tais confrontos nos revelaram os vestígios da eficácia das relações de força mediadas pelo poder de Estado burguês e os interesses das classes dominantes em manter a exploração do trabalho e a ordem do capital. Nesse entremeio de contradições, o site da Andes (Associação Nacional dos Docentes de Ensino Superior) enunciava, em sua tomada de posição assumida e não negada, o seguinte slogan: "NOSSOS DIREITOS CABEM NO PAPEL. EM NOSSAS MÃOS CABE A CONQUISTA”.

Em nosso rastreamento teórico-analítico e científico-político, durante esses momentos de confrontos e questionamento sobre o "fazer universidade", encontramos no site da Adufal (Associação Docentes da Universidade Federal de Alagoas) o seguinte enunciado: "GESTÃO RENOVAR E AVANÇAR NA LUTA", que sinalizava, parafrasticamente, as ressonâncias da mesma posição discursiva sindical da Andes em seu direcionamento político da "gestão" que parecia efetivamente querer "renovar" e "avançar na luta".

Vemos aqui o efeito de evidência da realidade do pensamento que faz com que o sindicato pense saber/fazer/dizer no lugar dos professores. Paradoxalmente, essa mesma "gestão", contrariando a base (assembleia dos professores que em sua maioria rejeitou a proposta do Governo), acabou assinando, juntamente com a Andes, o acordo oferecido pelo Governo Federal de aumento de 4\% para os professores, previsto para 2012. A assinatura desse acordo causou "revolta" entre os professores das diversas universidades federais que reivindicavam várias pautas que não se reduziam ao "aumento" salarial. Na Ufal, numa assembleia tensa, em 31/8/2011, deflagramos a greve, materializando, na prática política, o descontentamento-revolta com o sindicato "fraco" e "impotente" . Foi quando o site da Adufal, para noticiar o acontecimento da greve, "escolheu" dizê-la da seguinte forma: "Docentes da Ufal decidem cruzar os braços" (ADUFAL, em 31/8/2011).

Quando interrogamos a maneira de escrever/ler/interpretar os acontecimentos, podemos nos perguntar se algo falhou e/ou deslizou na forma material léxico-sintática desse enunciado. Mas, como afirma Pêcheux (1997a, p. 91), "é, pois, sobre a base dessas leis internas que se desenvolvem os processos discursivos, e não enquanto expressão de um puro pensamento, de uma pura atividade cognitiva, etc., que utilizaria 'acidentalmente' os sistemas lingüísticos”. Assim, não se trata de uma imperfeição da linguagem, até porque o discurso não é transmissão de informação, e entre o que o texto parece querer dizer e como ele significa discursivamente, há inúmeras diferenças. Sim, pois o discurso, sempre produzido por sujeitos históricos, deixa materializar sua filiação discursivo-ideológica. Nessa compreensão, apesar de ser dito num site do sindicato (lugar de possível resistência-

7 Essas palavras circularam durante o movimento grevista. 
-revolta), o enunciado, de modo discrepante, age contra os professores e revela sua filiação (subordinação), através do (im)pensado do pensamento, às redes de sentidos dominantes que consideram o "grevista" como "baderneiro", "preguiçoso", "mal-educado", "desrespeitoso", "arruaceiro", "ideológico" etc. ${ }^{8}$

Contudo, o confronto de sujeitos e sentidos não findou por aqui. Em 6 de setembro de 2011, em reunião de assembleia grevista, ocorreu a manifestação explícita do poder da ideologia dominante, que desde sempre já estava produzindo seus efeitos. Dezenas de professores que nunca participaram das assembleias durante essa greve compareceram para votar "contra" a greve e "contra" os grevistas. Contraditoriamente, exclamavam: "volta imediata ao trabalho!", "não estamos em greve!", "não se pode impedir que o funcionário público trabalhe!", "sou pago pelo Estado para trabalhar!". Entre palavras de ordem, gritos eufóricos, aplausos e vaias, os dizeres deixavam vestígios do abandono, ou mesmo, marcas da não incorporação do ideário socialista e comunista entre nós professores, e também da debilidade das forças sociais que têm como porta-voz o sindicato. O auditório ficou polarizado: professores tidos como porta-vozes do poder ("pelegos"/ "reacionários"/"estadistas") versus professores tidos como militantes ("agitadores"/ "ideológicos/"radicais"/“arruaceir os"). Como sabemos, "a história da produção dos conhecimentos não está acima ou separada da história da luta de classes, como o 'bom lado' da história se oporia ao 'mau lado'; essa história está inscrita, com sua especificidade, na história da luta de classes" (PÊCHEUX, 1997a, p. 190). Por isso, pudemos compreender que nessa conjuntura de confronto, o foco da questão deslizava para o reformismo, pois o embate se dava, equivocadamente, entre a categoria consigo mesma em suas diferentes posições-sujeito, já que chegamos, até mesmo, a ouvir gritos, quase clamores, de que se deveria "chamar a polícia!", numa tentativa de neutralizar a resistência-revolta.

Como não podemos deixar de encarar as questões discursivas como históricas e dialéticas, é preciso dizer que esses dois acontecimentos com que nos defrontamos, reproduzem, de modo distinto, as contradições da sociedade capitalista.

Segundo Pêcheux,

Este duplo caráter dos processos ideológicos (caráter regional e caráter de classe) permite compreender como as formações ideológicas e discursivas nas quais eles se inscrevem se referem necessariamente a "objetos" (como a Liberdade, a Ordem, a Igualdade, a Justiça, a Ciência, o Poder, etc.) que são ao mesmo tempo idênticos e antagonistas em relação a si mesmos, quer dizer, cuja unidade é submetida a uma divisão: o próprio da luta ideológica sob a dominação burguesa consiste em desenrolar-se em um mundo que não acaba nunca de se dividir em dois. (PÊCHEUX, 1990, p. 12)

Reconhecer isso exige compreender, de modo bastante rigoroso, como interpretamos a conjuntura histórica em que vivemos, e exige também a busca por alternativas a essas forças contrárias. Como vimos no discurso acadêmico-científico que remete à produção do conhecimento no "Prêmio Jovem Cientista" e na prática política e acadêmico-sindical que diz que "nossos direitos cabem no papel", em sua materialidade, Linguagem e História se fundem no/pelo sujeito em condições determinadas, para, dialeticamente, produzir sentidos e constituir e orientar as escolhas entre as alternativas possíveis. Aqui reencontramos o fundamento materialista e dialético, pois essa discursividade está intimamente ligada aos processos de organização (exploração) do trabalho do modo de produção capitalista, ou seja,

8 Essas palavras também circularam durante as assembleias dos professores. 


\section{Conexão Letras}

aos interesses socioideológicos em lutas na conjuntura histórica atual. É desse modo que tanto a Universidade, com suas instituições de pesquisas e fomento, quanto os sindicatos e suas representações políticas, acabam incorporando os valores dominantes e se dobrando ao sistema capitalista. Assim, jogam conforme as regras dominantes, inscrevendo o seu dizer nas relações de subordinação ao status quo e ao Estado, onde, como diz Lenin, as contradições de classes são inconciliáveis.

Nessas análises que retratam vestígios das condições ideológicas de reprodução/ transformação das relações materiais de produção, vimos que o processo dinâmico e contraditório do discurso, em suas condições históricas, faz com que a prática política pareça estar em decadência/banalização/despolitização, pois separa, pelas relações aparentemente disjuntivas: para o "Jovem cientista", o "incentivo" e o "Prêmio"; para os "professores-cientistas-militantes", a "polícia" e a "punição". Assim, cada um é chamado a ocupar um lugar e a agir por si mesmo, já que pensa ser a fonte do sentido que discursiviza.

Desse modo, fazer uma análise que pense a totalidade das questões tem implicações sérias em nossa prática, pois pode ajudar a evitar nossa decadência, despolitização e a banalização das categorias teóricas e da prática política. Nesse sentido, nos reportaremos novamente a Lukács, para lembrar como esse filósofo fez a crítica à especialização da Sociologia que separa a História das relações econômicas. De nosso ponto de vista, essa crítica contundente que Lukács estabelece também poderá nos fazer pensar sobre nossa prática enquanto analista de discurso:

A divisão capitalista do trabalho, portanto, não se limita apenas a submeter a si todos os campos da atividade material e intelectual, mas se insinua profundamente na alma de cada um, provocando nela profundas deformações, que se revelam posteriormente, sob variadas forma, nas diversas manifestações ideológicas. A covarde submissão a estes efeitos da divisão do trabalho, a passiva aceitação destas deformações psíquicas e morais, que são inclusive agravadas e enfeitadas pelos pensadores e escritores decadentes, constituem um dos traços mais importantes e essenciais do período de decadência. (LUKÁCS, 1981, p. 122).

Dissemos em trabalhos anteriores (SILVA SOBRINHO, 2007; 2009; 2011) que o real, em processo de transformação, possibilita um pensar configurado por lutas entre sentidos estabilizados e sentidos a se estabilizar, e que o discurso tem sua gênese nesse processo dinâmico e contraditório, no qual os sujeitos respondem às necessidades históricas. É preciso, pois, compreender o discurso no processo histórico de produção material da própria vida. Sendo assim, seja qual for o discurso que analisamos (científico e/ou político, por exemplo), é pressuposto que este não surge por autogênese, pois não se produz a si mesmo. É preciso que sujeitos históricos em condições de produção determinadas o produzam/reproduzam e o transformem, e isso é um processo dialético de efeito e trabalho que surge e interfere nas práticas sociais, pois os discursos fazem os sujeitos tanto quanto os sujeitos fazem os discursos. Por isso, não podemos ir ao real a fim de puramente (positivamente) descrevê-lo, nem podemos ficar nas evidências dos fenômenos empíricos. Não se trata de uma questão meramente "epistemológica", mas, sobretudo, das consequências sérias que se efetivam na práxis sócio-histórica. É preciso insistir, pois não basta apenas resistir; é preciso ousar se revoltar e intervir nos universos logicamente estabilizados e não estabilizados, para transformá-los de forma revolucionária, pois com as análises de discursos que realizamos também participamos do processo histórico, e esse é o caráter da práxis dialética. Por isso, a crítica deve ser radical e impiedosa, colocando em causa a ordem vigente, porque o capital é impiedoso. 


\section{Efeito de finalização: a quem estamos servindo quando fazemos AD?}

Karl Marx, Vladímir Lenin e Michel Pêcheux foram sujeitos ardentes e inquietos que se identificaram, contraidentificaram e desidentificaram com o fazer ciência e o fazer política de sua época. Assim, inscreveram-se nas lutas sociais de seu tempo histórico e compreenderam que a prática política e a prática científica não são disjuntas, pois a produção do conhecimento e suas intervenções nas práticas históricas não estão dissociadas dos interesses socioeconômicos de uma dada conjuntura. Por isso, é importante perguntar: com quem nos identificamos hoje e qual o nosso papel na práxis social constituída por relações de antagonismos inconciliáveis? Uma resposta cômoda seria dizer que não fazemos ciência - como tantos "colegas" nos acusam e nos "vulgarizam" por aí. Poderíamos também ainda, para fugir dessa questão, dizer que não existem mais classes sociais, nem relações de exploração de trabalho, nem ideologia - e assim seríamos uma "Ciência" (pós) moderna e despolitizada, em nome de uma cientificidade burguesa. Fazer isso, a nosso ver, implicaria estar no entremeio da evidência e do absurdo, e ainda se puxar histericamente pelos cabelos, o que seria outra forma de nos banalizarmos. Por isso, voltemos a repetir: é preciso desconfiar do óbvio, retomar o fundamento materialista e dialético e avançar na crítica radical, fazendo visíveis aos nossos olhos o (in)visível e o (in) suportável da nossa prática científica.

Nessas anotações finais, traremos ainda três citações, agora, não mais dos autores citados na epigrafe deste artigo, mas sim sobre eles: Marx, Lenin e Pêcheux a partir de George Lukács, Florestan Fernandes e Ana Zandwais. O propósito é ainda reafirmar, de modo contundente, as contribuições do marxismo em face da perspectiva da práxis dialética revolucionária, para chegar às raízes das contradições e intervir na materialidade sócio-histórica do real.

A relação com Marx é a verdadeira pedra de toque de todo intelectual que leva a sério o esclarecimento da sua própria concepção de mundo e do desenvolvimento social, particularmente a situação atual, a sua inserção nela e seu posicionamento frente a ela. A seriedade, o escrúpulo e a profundidade que dedica a este problema indicam se e em que medida o intelectual pretende, conscientemente ou não, furtar-se a uma clara tomada de posição em face das lutas históricas contemporâneas. (LUKÁCS, 2008, p. 37).

[Lenin] repôs o marxismo como política em suas bases revolucionárias, avançando do conhecimento da realidade política da sociedade de classes para o modo de organizar politicamente a sua transformação e destruição, como etapa preliminar à instauração do socialismo. (FLORESTAN, 1989, p. 21).

[...] ao tratar da teoria do discurso como teoria da determinação histórica dos processos semânticos, Pêcheux se aparta da ótica do historicismo-comparatista [...] Desde esta ótica, portanto, as relações do sujeito com a história e com os sentidos não podem mais ser tomadas como "representações" subjetivas que os sujeitos constroem sobre o real, mas, ao contrário, é o campo da prática concreta, da experiência, do vivido, que determina como o real precisa ser representado e significado como discurso. (ZANDWAIS, 2009, p. 27).

Trazer essas questões necessárias e inquietantes - do marxismo enquanto pedra de toque de todo intelectual e que exige conhecimento e posicionamento em face da sociedade de classes, ou seja, no campo da prática concreta - implica confrontar com nossa própria análise, perguntando-nos sempre a quem estamos efetivamente servindo quando fazemos $\mathrm{AD}$. 
Certamente essas interrogações tocam no efeito de desconhecimento ideológico que também nos afeta e, por isso, esse gesto pode ajudar a quebrar os espelhos da relação transparência/ opacidade de nossa interpelação-identificação para buscarmos visualizar nossa posição sujeito assumida, e/ou mesmo negada enquanto tal, ante as contradições da sociedade capitalista.

A consequência desse gesto é fazer pensar a implicação de nossas análises na práxis sócio-histórica e, sobretudo, impulsionar o questionamento do sujeito quanto à ordem existente e ao poder econômico dominante. Para nós, a prática analítica por si só não faz revolução; no entanto, ela possui força material cuja possibilidade de intervenção não pode ser negligenciada, pois não há transformação social sem a construção de críticas capazes de compreender as raízes dos efeitos de sentido que nos afetam e/ou constituem, que nos constroem e/ou desconstroem, ou mesmo, que nos mobilizam/desmobilizam. Por isso, em nossa incompletude de sujeitos históricos, marcados por contradições vivenciadas na práxis cotidiana, de um modo ou de outro, estamos comprometidos com a reprodução/ transformação das relações de produção e não podemos nos esquivar disso.

Ao articular o discurso e as condições de produção do dizer, o analista não escapa ao entrelaçamento das lutas ideológicas em jogo na conjuntura histórica. Esse gesto exige o enfrentamento aos desafios históricos, marcados pela exploração do trabalho, pelo caráter competitivo, excludente e violento da sociabilidade regida pela lógica do capital. É preciso, então, avaliar nossa prática e recuperar o nexo materialista da relação dialética objetividade-subjetividade na obra de Pêcheux, especialmente sobre a teoria das ideologias, a produção de conhecimento e a prática política revolucionária, tal como ele mesmo enfatizou: "a prática teórica do materialismo histórico pressupõe e implica a prática política do proletariado, com o vínculo que as une: em suma, trata-se da formação histórica de uma política científica, contemporânea à formação histórica do movimento operário, e ligada, de seu interior, a um conhecimento científico da luta de classes" (PÊCHEUX, 1997a, p. 203).

Talvez estejamos cada vez mais distantes e nos distanciando da classe operária, e deixando de compreender o discurso a partir das bases filosóficas do materialismo histórico-dialético. Nosso afastamento/distanciamento se dá no confronto com o real, particularmente quando reduzimos as análises a querelas especulativas sem repor a questão das relações de trabalho, do estranhamento e da lógica do capital de modo concreto. Retomar a AD numa perspectiva marxiana é também, para o analista de discurso, articular dialeticamente teoria e prática, trabalhando concretamente no ponto nodal/crucial das contradições da reprodução/transformação das relações de produção, evitando e, sobretudo, recusando o caráter cientificista-acadêmico-universitário que pode solapar o avanço da $\mathrm{AD}$ e afetar negativamente o processo histórico revolucionário.

Para finalizar este nosso percurso, retomaremos a afirmativa de Pêcheux que diz: "é preciso ousar se revoltar", para, assim, reclamar por sua atualidade, pois ela nos remete à prática histórica, ou seja, às atividades dos sujeitos nas relações de trabalho, mediadas pelas práticas discursivas constituída nas relações de classes em incessante conflito na sociedade capitalista. O que nos assombra hoje não são os fantasmas de uma (pós) modernidade tardia, pois nesses mais de quarenta anos de AD a "pré-história da sociedade humana" não findou e o capital continua voraz em sua existência, pois, de modo "sofisticado" e também "selvagem", continua a intensificação da exploração do trabalho, que permanece impiedosa e mordaz.

Parece "óbvio" que houve mudanças, mas não houve ainda transformações revolucionárias que eliminassem definitivamente a sociedade de classes e suas desigualdades sociais. Ainda não vivemos em outro mundo possível, nem instauramos uma sociedade sobre 
novos fundamentos; ao contrário, as regras continuam dissimuladamente orientadas pela lógica capitalista. Sabemos que dizer isso poderá despertar controvérsias, mas insistimos: o que de fato temos produzido de revolucionário? Ao que parece, entre nós, analistas de discursos, prevalece um relativo "consenso" sobre o que investigamos, ou seja, "o discurso enquanto efeitos de sentido entre os interlocutores". Todavia, esses sentidos se tornam bastante complexos, contraditórios, e até mesmo traumáticos quando efetivamente tocamos de modo radical nos antagonismos inconciliáveis das classes sociais, questionamos suas evidências e voltamos a nos perguntar: o que é o discurso? O que são efeitos de sentido? Quem são os interlocutores? O que buscamos? Por fim, ou talvez ainda, por início: quem somos e o que fazemos? Afinal, como diz Michel Pêcheux, é preciso tomar partido pelo fogo de um trabalho crítico, e fazer isso é uma questão de ética, política e responsabilidade.

\section{Referências}

COURTINE, Jean-Jacques. [1991]. O discurso inatingível: marxismo e linguística (1965-1985). In Cadernos de tradução. UFRGS, Porto Alegre: ${ }^{\circ}$ 6, abril-junho, 1999. COUTINHO, Carlos. [1971]. O estruturalismo e a miséria da razão. Rio de Janeiro: Paz e Terra, 1972.

ENGELS, F. [1976]. Sobre o papel do trabalho na transformação do macaco em homem. In ANTUNES, Ricardo. A dialética do trabalho. São Paulo: Expressão Popular, 2004. FERNANDES, Florestan. Introdução. In FERNANDES, F. (Org.). Lenin. Coleção Grandes cientistas sociais - Política. São Paulo: Ática, 1989.

LÉNINE, Vladímir. [1902]. Que fazer? In V. I. LÉNINE: Obras escolhidas. Tomo 1. 1977. LUKÁCS, Georg. [1933]. Meu caminho para Marx. In LUKÁCS, G. Socialismo e democratização: escritos políticos 1956-1971. Rio de Janeiro: Editora UFRJ, 2008.

. [1938]. A decadência ideológica e as condições gerais da pesquisa científica.

In NETTO, J. P. (Org.). Georg Lukács. Coleção Grandes cientistas sociais. São Paulo: Ática, 1981.

MALDIDIER, Denise. [1990]. A inquietação do discurso: (Re) ler Michel Pêcheux hoje. Campinas: Pontes, 2003. MARX, Karl \& ENGELS, F. [1845]. A ideologia alemã. São Paulo: Martins Fontes, 1998.

MARX, Karl \& ENGELS, F. [1848]. Manifesto do Partido Comunista. São Paulo: Martin Claret, 2001.

MARX, Karl. [1843]. Crítica da filosofia do direito de Hegel - Introdução. In MARX, K. Crítica da filosofia do direito de Hegel. São Paulo: Boitempo, 2010.

MARX, Karl. Manuscritos econômico-filosóficos [1844]. São Paulo: Boitempo, 2004. ORLANDI, Eni. Interpretação: autoria, leitura e efeitos do trabalho simbólico.

Petrópolis: Vozes, 1996.

PÊCHEUX, Michel. [1975]. Semântica e Discurso: uma crítica à afirmação do óbvio. Campinas: Editora da Unicamp, 1997a.

PÊCHEUX, Michel. [1978]. Só há causa daquilo que falha ou o inverno político francês: início de uma retificação. In Semântica e Discurso. Campinas: Editora da Unicamp, 1997b.

PÊCHEUX, Michel. [1982]. Delimitações, inversões, deslocamentos. In Cadernos de estudos linguísticos, $\mathrm{n}^{\circ}$ 19. Campinas, SP: Editora da Unicamp, 1990.

PÊCHEUX, Michel. [1983]. O Discurso: estrutura ou acontecimento. Campinas:

Pontes, 2002. 


\section{Conexão Letras}

SILVA SOBRINHO, Helson. Discurso, velhice e classes sociais: a dinâmica contraditória do dizer agitando as filiações de sentidos na processualidade histórica. Maceió:

Edufal, 2007.

SILVA SOBRINHO, Helson. Os andaimes suspensos do discurso nos alicerces do real. In INDUSKY, F. et al. O discurso na contemporaneidade. São Carlos: Claraluz, 2009. SILVA SOBRINHO, Helson. Análise do Discurso e a insuportável luta de classes na teoria e na prática. In TFOUNI, L. et alii (Orgs.). A Análise do Discurso e suas Interfaces. São Carlos: Pedro \& João Editores, 2011.

VÁZQUEZ, A. Sánchez. [1967]. Filosofia da práxis. São Paulo: Expressão Popular, 2007. ZANDWAIS, Ana. Perspectivas da Análise do Discurso fundada por Michel Pêcheux na França. Série Cogitare. Vol. 8. Programa de Pós-graduação em Letras da UFSM. Santa Maria, 2009. 